\title{
DOES BOARD USAGE OF KNOWLEDGE AND SKILLS AFFECT INTERNATIONALIZATION PERFORMANCE OF SMES? A CASE OF LITHUANIA
}

\author{
Monika BUŽAVAITE் $@$, Renata KORSAKIENĖ (ํ) \\ Department of Management, Vilnius Gediminas Technical University, Vilnius, Lithuania
}

Received 15 March 2021; accepted 14 July 2021 ; first published online 14 Deccember 2021

\begin{abstract}
Internationalization of SMEs is encouraged by the advantages of new environmental conditions and appealing business opportunities, but remains a challenging process. Top management teams and more specifically board of directors appear to be a critical determinant in addressing internationalization issues. In recent years, investigation of boards in small firms' context has been an interest of scholars, however few investigated characteristics of human capital. This study aims to investigate whether board usage of knowledge and skills is a mediator linking characteristics of human capital of board and internationalization performance of SMEs in Lithuania. The results revealed that usage of knowledge and skills mediates the relationships between international business skills and internationalization performance. Obtained results contribute to international entrepreneurship and upper-echelons theories by highlighting the role of the board in SMEs and linking it to higher internationalization performance through their usage of knowledge and skills. This study fills the research gap and extends the extant studies in internationalization of SMEs. First, the study responds to the need to investigate how board's capital affect internationalization. Secondly, the study responds to the need to go beyond input-output models.
\end{abstract}

Keywords: internationalization, internationalization performance, board, board capital, human capital, SMEs.

JEL Classification: M10, M13, M19.

\section{Introduction}

Small and medium sized enterprises (SMEs) are perceived as the significant contributors of national economies due to high input in the new jobs' creation and value added. Internationalization as an incremental involvement in international markets helps to increase the profit of SMEs and accordingly support the local economies by the higher amount in taxes. Moreover, internationalization strategies appear to be critical for SMEs due to globalization processes and increased competition in local markets (Chen et al., 2017). Though SMEs are

\footnotetext{
${ }^{\star}$ Corresponding author. E-mail: renata.korsakiene@vilniustech.lt
} 
tended to focus on the local markets, a number of small businesses eventually identify various opportunities abroad. Therefore, internationalization of SMEs has been attracting the interest of scholars and policy makers in the last three decades.

Though internationalization of SMEs is encouraged by the advantages of new environmental conditions and appealing business opportunities, this process still has some challenges for SMEs due to its smallness and newness and subsequently, resource scarcity (Korsakiene et al., 2019a). Moreover, internationalization is perceived as highly risky and uncertain process, which is accompanied by complexity of issues and increase the demand for resources and capabilities. Top management teams and more specifically board of directors appear to be a critical determinant in addressing internationalization issues (Chen et al., 2017). Sometimes defined as "supra top management team", the board is composed of highly competent individuals with rich human capital (Rivas, 2012) and thus, the provision of necessary resources for business internationalization in terms of knowledge and relationships, identification of new opportunities and collection of relevant information are expected (Calabrò \& Mussolino, 2013).

The investigations in small business context revealed the involvement of board in strategic decisions making (Bjørnåli \& Aspelund, 2012; Calabrò \& Mussolino, 2013), but few investigated human capital. The previously conducted studies suggest that human capital characteristics of board, such as international business skills, managerial competence, and risk-taking characteristics might positively affect internationalization performance (Barroso et al., 2011; Rivas, 2012; Hsu et al., 2011). However, human capital, accumulated by each board member is perceived as not sufficient for board tasks (Arzubiaga et al., 2018). Considering work of board members, the available expertise and skills of board members should be actively provided in the meetings (Zattoni et al., 2015). Moreover, usage of knowledge and skills allows to ensure effective group work and subsequently, contribute to internationalization performance Accordingly, this study aims to investigate whether board usage of knowledge and skills is a mediator linking human capital characteristics of board and internationalization performance of SMEs.

Notably, board members are skilled in the provision of necessary resources, social networks and development of the firm's reputation (Barroso-Castro et al., 2020). The professionalism of board members accumulated into board capital is crucial for the firm's management support by participating in the strategic decisions such as internationalization. While SMEs encounter a number of obstacles during international expansion, the board of directors' presence in SMEs foster international sales through personal connections and previous international business experience and thus, is perceived as more advantageous as compared to the firms without boards. However, the scientific studies on the impact of board members' knowledge and expertise in such strategic areas as international expansion remains scant (Bjørnåli \& Aspelund, 2012; Ricci et al., 2019). Therefore, the phenomenon of board capital and the impact on the small firm's internationalization require deeper investigations. This study fills the research gap and extends the extant studies in internationalization of SMEs. First, the study responds to the need to investigate how characteristics of board's capital affect internationalization performance (Chen et al., 2017). Secondly, the study responds to the need to go beyond input-output models (Zattoni et al., 2015). 
While investigated in the developed countries context, the studies on boards in the context of Central and Eastern Europe are limited. Therefore, this study tests developed hypotheses using data from Lithuanian SMEs. In 2018, SMEs have generated 69.4\% of value added and contributed to $75.9 \%$ of employment in Lithuania (European Commission, 2019). In spite of the ambitions to internationalize, the exports of Lithuanian SMEs were lower in 2018 as compared to 2017 (European Commission, 2019) what remains the concerns of management and policymakers (Korsakienè et al., 2019b).

The paper is structured as follows. First, the theoretical considerations on internationalization, human capital and the role of the usage of knowledge and skills are provided, and accordingly, the hypotheses are developed. The second section provides information on research sample, variables, and methods. The quantitative research is supported by OLS modelling and leads to the testing of developed hypotheses. The third part provides research results. The final section provides discussion and conclusions part.

\section{Theoretical framework and hypotheses development}

Defining internationalization, the board in small firms, and the role of board capital. International expansion of SMEs appears to be a significant way for business survival and growth, achieved through economies of scale, access to new knowledge and manufacturing efficiencies. Therefore, internationalization, defined as gradual involvement in international markets, is perceived as one of the most important strategic decisions of SMEs, which requires considerable efforts and resources (Bagheri et al. 2019). However, small firms are limited by the liabilities of smallness and newness, which considerably limit international activities. The vast literature on internationalization emphasizes different external and internal factors, impacting successful performance in international markets. A stream of studies, stemming from upper-echelons theory, suggest that strategic decisions such as internationalization are determined by human capital of top managers (Bužavaitė \& Korsakienè, 2019; Korsakienè et al., 2019a). Meanwhile, governance literature emphasizes both the role and contribution of the board of directors in the development of the firm's capabilities to cope with the complexity of issues (Barroso-Castro et al., 2020).

The interest of researchers in the board's impact at the strategic level has been increased in the recent years. The investigations in small business context disclosed, that board of directors was involved in strategic decisions of start-ups (Bjørnåli \& Aspelund, 2012) and family SMEs (Calabrò \& Mussolino, 2013). Though originated in the context of large firms, the concept of board has been extended in the international entrepreneurship literature. For instance, some studies even extended the concept of top management teams of entrepreneurial firms by including board of directors (Bjørnåli \& Aspelund, 2012). Thus, we conceptualize board of small firms as composed of internal (holds the position of the manager) and / or external (does not hold the position of the manager) managers, who represent the interests of the business owner (s) and perform advisory, strategic, monitoring, control functions in the firm and participate in regular meetings. It is a formal or informal intermediate link between the firm's shareholders and executives, who have useful business relationships that can help the firm get the information or other resources it needs (Barroso-Castro et al., 2020; Puthusserry et al., 2021). 
The literature attempted to explain board capital by adopting resource-based and resource dependence theories. While resource dependence theory emphasizes the dependence of the firm's success on external resources, the outside board members appear to be crucial in maximizing the performance of the firm. Moreover, board's human capital, comprised of skills, knowledge and competence (Kungwansupaphan \& Siengthai, 2014), is perceived as the most valuable resource of the firm and potential source for competitive advantage. Therefore, the board of directors' act as management team's advisors or thin-tanks due to accumulated human capital, which includes knowledge, competence, skills, obtained through previous work experience, and substitute capital shortages of other top managers (Bjørnåli \& Aspelund, 2012).

The impact of board's human capital characteristics on internationalization performance. The studies suggest that board of directors bring intangible resources to the firm, which are integrated in unique ways and influence firm performance (Barroso et al., 2011). International expansion of business is perceived as highly risky, which involves complex managerial work (Chen et al., 2017). Accordingly, board members must accumulate human capital, which leads to a better understanding of international environments, international activities and strategies. The literature suggests that international business skills, as the important component of human capital, are obtained through different sources: expertise in technology, marketing, education, networks and working in the firms abroad (Kungwansupaphan \& Siengthai, 2014). Apparently, international business skills of board members may help small firms tackle the issue of liability of foreignness (Barroso et al., 2011; Chen et al., 2017). The explanation resides in the fact that board members with international business skills are more effective in the advisory role as compared to the board members without such skills (Oxelheim et al., 2013). Furthermore, the scholars assert that top managers with greater international business skills are likely to have a greater level of international business knowledge, such as institutional knowledge, business knowledge and knowledge in internationalization (Kungwansupaphan \& Siengthai, 2014). In addition, managerial competence, which includes firm-specific, industry specific and related industry skills, appears to be important in effective decision-making process and duties of board (Åberg \& Torchia, 2020). Taking into consideration that board members rely on accumulated knowledge and skills, managerial competence shape key assumptions, priorities and involvement in such strategic decisions as internationalization. As such the studies have revealed that firm and industry related expertise of board positively influenced international expansion and the firm's degree of international diversification (Barroso et al., 2011). Furthermore, prior studies highlighted the positive impact of risk-taking characteristic of top decision-makers on internationalization of the firm (Hsu et al., 2011). Taking into consideration the positive associations of board and different outcomes of organization (Ricci et al., 2019), we argue that characteristics of board capital, shaped by international business skills, managerial competence and risk-taking characteristics of its members, positively influence internationalization performance. Grounded on these arguments we can hypothesize:

H1a: international business skills of the board have positive impact on internationalization performance.

$H 1 b$ : managerial competence of the board has positive impact on internationalization performance. 
H1c: risk-taking characteristics of the board have positive impact on internationalization performance.

The impact of board's human capital characteristics on usage of knowledge and skills. The literature on board emphasizes the use of knowledge and skills (Åberg et al., 2019). The explanation resides in the fact that availability of knowledge and skills does not guarantee their application. In other words, human capital, accumulated by each board member is perceived as not sufficient for board tasks (Arzubiaga et al., 2018) and thus, does not guarantee direct contribution to the group decision making. Moreover, the decision-making of board members is described as episodic and thus, the behaviour is highly interdependent. The scholars suggest that available expertise and skills of board members should be actively provided in the meetings (Zattoni et al., 2015). Interactions between board members let them display individual human capital, which affects their abilities to use their capabilities in coordinated manner to reach problem solving potential. Moreover, human capital characteristics of board members affect their capability to solve various obstacles during internationalization process.

Notably, several conditions appear to be relevant for the use of knowledge and skills of board members. For instance, the extent each member knows other's competences (Kearney et al., 2009) and social ties among members lead to more effective use of knowledge and skills. Furthermore, the match of work characteristic and board members' competence influences efficiency of the usage of knowledge and skills. Therefore, acceptable coordination of tasks creates conductive circumstances for each board member to apply their human capital in order to reach the highest potential of their board capital as a team. Finally, the usage of available knowledge and skills when particular issue appears impacts group's effectiveness. Considering the fact that boards are involved in complex decision-making process (Åberg et al., 2019), we argue that board capital characteristics, shaped by international business skills, managerial competence and risk-taking characteristics of its members, positively influence usage of knowledge and skills. Thus, we can hypothesize:

$H 2 a$ : International business skills of the board has positive impact on usage of knowledge and skills.

$H 2 b$ : Managerial competence of the board has positive impact on usage of knowledge and skills.

$H 2 c$ : Risk-taking characteristics of the board has positive impact on usage of knowledge and skills.

Usage of knowledge and skills as mediator. The studies, investigating board's processes, suggest that there is a relationship between board characteristics, decision-making process and firm performance (Roffia et al., 2021). They show that board characteristics positively influence usage of knowledge and skills. The studies, grounded on resource dependence theory, revealed that board members' capital is crucial in the decision-making process and fulfillment of tasks (Zattoni et al., 2015). Moreover, usage of knowledge and skills in board decision-making process positively influences performance of the firm. The scholars have mostly investigated various measures of usage of knowledge and skills and confirmed mediating effect on the relationship between available resources and whole company performance. Meanwhile, international decisions are perceived as very complex and different experiences of board members might even hinder strategic decisions (Chen et al., 2017). Therefore, the 
effectiveness of team is impacted by cooperation and exchange of information among board members. Zattoni et al. (2015) emphasized that skills and knowledge coordination of the board ensure effectively working team by assigning the specific tasks to the most knowledgeable directors in that area. Such practice of board processes leads to effectively delivered tasks and positively contribute to internationalization performance. Therefore, we argue that usage of knowledge and skills positively mediate the relationship between international business skills, managerial competence, risk-taking characteristics of its members and internationalization performance. On the other hand, low provision of knowledge and skills may hinder contribution of board members' human capital characteristics to internationalization performance of the firm. Grounded on these arguments we can hypothesize:

$H 3 a$ : Usage of knowledge and skills positively mediate the relationship between international business skills and internationalization performance.

$H 3 b$ : Usage of knowledge and skills positively mediate the relationship between managerial competence and internationalization performance.

$H 3 c$ : Usage of knowledge and skills positively mediate the relationship between risktaking characteristics and internationalization performance.

The hypotheses are presented in the conceptual model (Figure 1).

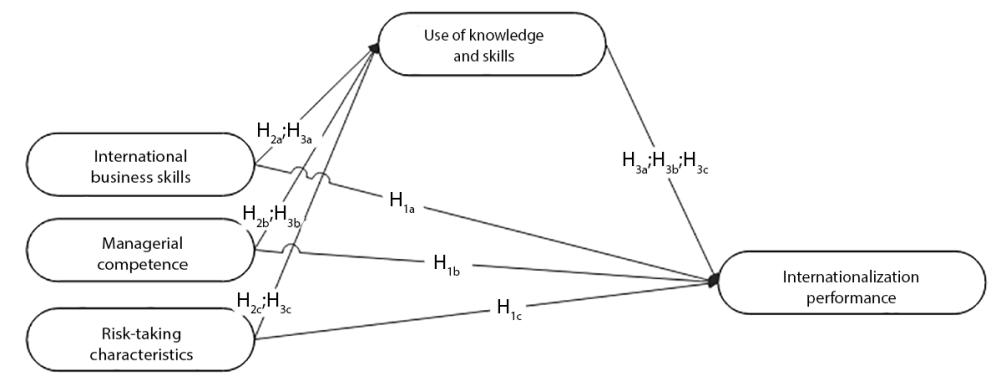

Figure 1. Conceptual model (own elaboration)

\section{Sample, variables, and methods}

A survey method, which is very common in social sciences, was applied for the purpose to collect empirical data. Depending on the data collection purpose and its relationship to the theory, confirmatory survey type was used. Collected data were used for the hypotheses testing and investigation of relations among the concepts. The sample consists of Lithuanian SMEs included in two databases of Enterprise Lithuania: database of exporting SMEs and database of start-ups. These databases include 2360 firms, which meet the criteria of SMEs. This approach was applied considering a lack of available data on SMEs with functioning board and the absence of strict regulations regarding it. Though it is optional to have a board, according to the Lithuanian law for limited liability companies, the boards are more common in medium-sized firms and start-ups. The need for board arises due to business expansion and a lack of resources inherent in SMEs, which need to address the strategic challenges such as internationalization. Meanwhile, the boards of start-ups, composed of external managers, 
entrepreneurs and investors provide higher control of the firms' activities, share knowledge and act as a think-tank.

A questionnaire was designed and pre-tested by inviting several representatives from SMEs with appropriate management education background and managerial work experience to provide feedback on the clarity of instrument. According to the received recommendations from the business representatives, the instrument was modified and the clarity was enhanced. The survey was conducted online in June-November, 2020. The electronic mail inviting to fill the questionnaire with included link to the survey was sent to the CEOs of 2360 SMEs. CEOs were selected as the potentially richest information source about the strategy, performance and processes in SMEs (Bjørnåli \& Aspelund, 2012). By filling the survey, the respondents had the possibility to mark if they would like to receive the results of this study as incentives. The reminders to fill the survey were sent within seven days after the initial invitation to participate in the research by filling survey. In total, 103 responses, which matched our interest were selected for further analysis. Considering recommendations (Rogelberg \& Stanton, 2007), the non-response bias was evaluated by adopting a wave analysis and comparing early and late respondents on the main survey variables. The statistical differences were not disclosed and thus, nonresponse bias was not a problem of this study.

\subsection{Variables and measures}

Grounded on previous investigations, the dependent variable - internationalization performance was measured by applying subjective indicators (Bagheri et al., 2019). The literature on SMEs internationalization includes objective and subjective measurements (Hult et al., 2008). However, the reluctance of owners/managers to disclose the data appears to be the major obstacle for researchers (Gerschewski et al., 2015). Moreover, some scholars point out the issues related to manipulation of profitability and accounting data with the purpose of tax evasion (Bamiatzi \& Kirchmaier, 2014). Furthermore, the firms vary in terms of their size and operational focus on growth or on cash flow and employment stability and thus, the significant variation of objective measures across SMEs has been noted (Bagheri et al., 2019). Finally, a positive association of subjective indicators to objective performance have been observed in the scientific literature (Gerschewski et al., 2015) and led to the wider application of subjective indicators (Bagheri et al., 2019). Referring to Gerschewski et al. (2015), internationalization performance of the firm was measured by considering operational performance, financial performance and perceived success of international performance. The fourteen-item scale was measured by applying five-point Likert-scale ranging from (1) unsuccessful (5) very successful.

The first independent variable of human capital - international business skills was measured by five-items scale ranging from (1) little to (5) very much. The variable was measured at the level of the board and included the following skills: expertise in technology and communication, marketing experience, international business education, personal networks and relationships abroad and general international work experience (Kungwansupaphan \& Siengthai, 2014). 
Managerial competence of board was measured by six-items scale ranging from (1) very little to (5) very much and comprised firm-specific, industry specific and related industry skills (Åberg \& Torchia, 2020).

Risk-taking characteristics of board was measured by four-items scale ranging from (1) very much disagree to (5) very much agree and assessed the board's attitudes towards uncertainty (Hsu et al., 2011). The variables measured (a) sharing of beliefs about the future of organization, (b) encouragement of change and implementation of improvement culture, (c) the unity of purpose throughout the board and (d) the existence of planning process which regularly sets short-term and long-term goals of board.

The scholars consider human capital as important source of internationalization mediated by capabilities (Karami \& Tang, 2019), which refer to the usage of knowledge and skills. Based on Zattoni et al. (2015), the usage of knowledge and skills was measured by three-items scale ranging from (1) very much disagree to (5) very much agree. The variable measured (a) the extent to which board members know each other's competences; (b) the match between board's competence and their work character; (c) the usage of knowledge of board when the issue appears.

Considering previous studies, we included control variables at the firm level: firm size, timing of international market entry, board size, firm age and industry (Barroso et al., 2011; Barroso-Castro et al., 2020). The firm size was measured by the number of employees and thus, each respondent was assigned to the following groups: 1 - with up to 10 employees, 2 - from 11 to 49 employees and 3 from 50 to 249 employees (Bjørnåli et al., 2016). Empirical results confirmed that firm size referring to employees' number has a positive impact on internationalization scale (Korsakienè et al., 2019b). Timing of international market entry was measured in years by considering how early the firm initiated international activities. The respondents were assigned to the following groups: up to 2 years; $2-4$ years; $4-5$ and more than 5 years after the firm's establishment. These categories were coded accordingly from 1 to 4 . The board size refers to the actual number of members on the board of SMEs (Åberg \& Torchia, 2020). The firm age variable was included as a number of years since the business was formally established. The variable was coded as a dummy variable for each sector. Sections of economic activities were adapted from NACE Rev.2 / statistical classification of economic activities in the EU. Notably, each respondent was allocated to the following groups: Manufacturing, mining and quarrying, and other industry (sections B, C, D and E); Construction (section F); Wholesale and retail trade, transportation and storage, accommodation and food service activities (sections G, H, I). The variable was coded as a dummy variable for each sector.

\subsection{Controlling for common method bias}

Common method variance might occur due to the measurement method and thus, is considered as a potential problem in behavioral research (Podsakoff, 2003). Notably, any errors in the measurement can negatively influence the validity of conclusions about the relationships. The data in this study are gathered from one source i.e., by asking the same respondent to evaluate dependent and independent factors. Therefore, we controlled for common method 
bias. Aiming to reduce response patterns and maintain engagement of respondents, negatively worded (reverse-coded) items were included in the questionnaire (Podsakoff, 2003). Secondly, the counterbalancing questions were included, aiming to neutralize mood stages related to item-context. Moreover, the anonymity of respondents was guaranteed. Statistically, common method bias can be indicated by Harman's one-factor (or single-factor) test as a post hoc statistical analysis, when all analyzed items are gathered into one factor and its variance is estimated. If one factor explains more than $50 \%$ of the variance of the sample, then common method bias could be present. All constructs used in this research were loaded into one explanatory factor, which resulted in $35.97 \%$ of explained sample's variance (Podsakoff, 2003).

\subsection{Analytical approach}

\subsubsection{Construct validity and reliability}

Reliability of the constructs refers to the internal consistency of items and is measured by Cronbach's alpha coefficient. Calculated Cronbach's alphas were as follows: for international business skills -0.82 , for risk-taking characteristics -0.815 , for usage of knowledge and skills -0.86 , for managerial competence -0.901 . Moreover, calculated Cronbach's alpha for international performance was 0.955 . It is assumed that Cronbach's alpha should be 0.70 or higher in the scientific research, to approve that set of questions are reconciled. To conclude, all scales used in the research are reliable, because Cronbach's alpha coefficients vary from 0.815 to 0.955 . Furthermore, composite reliability (CR) was confirmed by values exceeding the 0.7 threshold and varying from 0.879 to 0.979 . In addition, the square root of the average variance extracted (AVE) value should exceed 0.50 , aiming to reveal that it is adequate for convergent validity. The results indicate, that the AVE of all constructs is above the threshold 0.5 (AVE > 0.611). Since the composite reliability is achieved (the values of all determinants are above 0.7 ), we can make a conclusion, that the average variance extracted is also acceptable.

Construct validity was considered by exploring principal component factor analysis with the varimax rotation with Kaiser normalization in order to clarify the relationship among the factors. Considered variables fell into five factors. All factors' loadings were acceptable (the lowest value was 0.719 ). Bartlett's test of sphericity shows if the correlations between variables are statistically significant, while and Keiser-Meyer-Olkin measure indicates sampling adequacy, whether the correlations of the variable pairs are explained other variables. Data is suitable for factor analysis, when the Bartlett sphericity test is significant (significance level $\mathrm{p}<0.05$ ) and the KMO coefficient (it can be between 0 and 1 ) is higher than 0.6 if KMO less than 0.5, this data is not suitable for factor analysis. In our case, Bartlett's test of sphericity for all constructs indicated that the correlation matrix has significant correlations (sig. $=0.000)$. In addition, $\mathrm{KMO}$ value confirmed that data of all constructs are suitable for factor analysis $(0.706<\mathrm{KMO}<0.885)$.

\subsubsection{Data analysis}

The main analysis included OLS regression models, which were used for the hypotheses testing. Mediation analysis was performed according to Preacher and Hayes (2008) by applying a 
95\% confidence interval and setting bootstrap samples number to 5000. Notably, bootstrapping method is suggested to be applied over other methods in testing mediation (Hayes et al., 2017). Thus, our approach corresponds to other studies on boards, which adopt PROCESS for testing various mediated and moderated models (e.g., Åberg \& Torchia, 2020). The calculations were delivered by using SPSS 25 version and PROCESS Procedure for SPSS Version 3.5. Model estimation in the PROCESS macro for SPSS is implemented by ordinary least squares regression-based path analysis (Hayes et al., 2017). Finally, Sobel test was applied aiming to confirm previously supported mediations.

Considering the multicollinearity problem, which influences unstable regression coefficients, the variance inflation factor (VIF) was calculated. The results revealed that the multicollinearity problem does not exist. The VIF values ranges from 1.084 to 2.238 and are acceptable. Moreover, the correlation between any two analyzed variables did not exceeded 0.9 and VIF value for all constructs did not exceeded 4.

\section{Results}

The majority of firms in the sample belong to the following sectors: manufacturing $(29.41 \%)$, wholesale \& retail trade $(25.88 \%)$, and construction $(22.35 \%)$. About half of the firms in the sample were small firms having 11-50 employees. A similar number of the firms in the sample were medium-sized firms (40.78\%) having more than 50, but less than 250 employees. The lowest number of the firms were micro (12.62\%) having up to 10 employees. More than half of SMEs (54.5\%) started international activities in less than two years after their establishment. Meanwhile, $27.7 \%$ of the firms started internationalization after more than five years. The minority of SMEs became active in international markets in 2-3 years (8\%) or $4-5$ years $(9.8 \%)$ after the establishment. The board of directors among sampled SMEs usually consist of 3 members (39.81\%) respondents. The results of the descriptive statistics and correlations among variables are presented in Table 1.

Table 1. Descriptive and correlation data (source: own calculations)

\begin{tabular}{|l|c|c|c|c|c|c|c|c|c|c|c|}
\hline & 1 & 2 & 3 & 4 & 5 & 6 & 7 & 8 & 9 & 10 & 11 \\
\hline $\begin{array}{l}\text { 1. Internatio- } \\
\text { nalization } \\
\text { performance }\end{array}$ & 1 & & & & & & & & & & \\
\hline $\begin{array}{l}\text { 2. Internatio- } \\
\text { nal business } \\
\text { skills }\end{array}$ & $.377^{* *}$ & 1 & & & & & & & & & \\
\hline $\begin{array}{l}\text { 3. Managerial } \\
\text { competence }\end{array}$ & $.353^{* *}$ & $.585^{* *}$ & 1 & & & & & & & & \\
\hline $\begin{array}{l}4 . \text { Risk-taking } \\
\text { characteristics }\end{array}$ & $.405^{* *}$ & $.301^{* *}$ & $.498^{* *}$ & 1 & & & & & & & \\
\hline $\begin{array}{l}\text { 5. Usage of } \\
\text { knowledge } \\
\text { and skills }\end{array}$ & $.320^{* *}$ & $.363^{* *}$ & $.541^{* *}$ & $.678^{* *}$ & 1.000 & & & & & & \\
\hline
\end{tabular}


End of Table 1

\begin{tabular}{|l|c|c|c|c|c|c|c|c|c|c|c|}
\hline & 1 & 2 & 3 & 4 & 5 & 6 & 7 & 8 & 9 & 10 & 11 \\
\hline $\begin{array}{l}\text { 6. Sector: } \\
\text { Manu- } \\
\text { facturing, } \\
\text { mining and } \\
\text { quarrying and } \\
\text { other industry }\end{array}$ & $.344^{* *}$ & 0.046 & -0.003 & 0.151 & 0.030 & 1.000 & & & & & \\
\hline $\begin{array}{l}\text { 7. Sector: } \\
\text { Construction }\end{array}$ & $-.269^{* *}$ & -0.142 & -0.035 & -0.089 & 0.082 & $-.269^{* *}$ & 1.000 & & & & \\
\hline 8. Firm size & 0.161 & 0.039 & 0.035 & -0.090 & 0.072 & 0.015 & -0.023 & 1.000 & & & \\
\hline $\begin{array}{l}\text { 9. Timing of } \\
\text { international } \\
\text { market entry }\end{array}$ & $-.228^{*}$ & -0.137 & -0.144 & -0.095 & -0.145 & -0.051 & 0.067 & -0.003 & 1.000 & & \\
\hline 10. Board size & 0.109 & 0.106 & 0.078 & -0.075 & 0.071 & 0.092 & -0.058 & 0.096 & $.274^{* *}$ & 1.000 & \\
\hline 11. Firm age & -0.103 & 0.043 & 0.027 & $-.198^{*}$ & -0.037 & 0.101 & 0.034 & 0.167 & $.329^{* *}$ & $.240^{*}$ & 1.000 \\
\hline Minimum & 1 & 1 & 1 & 1 & 1 & 0 & 0 & 1 & 1 & 1 & 1 \\
\hline Maximum & 5 & 5 & 5 & 5 & 5 & 1 & 1 & 3 & 4 & 12 & 74 \\
\hline Mean & 2.937 & 3.273 & 3.892 & 3.859 & 0.019 & 0.2427 & 0.11845 & 2.27 & 2.08 & 3.62 & 16.51 \\
\hline SD & 1.155 & 0.918 & 0.805 & 0.795 & 0.139 & 0.431 & 0.390 & 0.689 & 1.319 & 2.087 & 11.265 \\
\hline
\end{tabular}

Note: $\mathrm{N}=103 ;{ }^{\star}$ Correlation is significant at the 0.05 level (2-tailed). ${ }^{\star *}-$ at the 0.01 level (2-tailed).

The analysis of descriptive statistics and correlations revealed some insights about the relationships among the variables. Internationalization performance was positively related to international business skills, managerial competence and risk-taking characteristics. The usage of knowledge and skills as mediator also positively correlates with all main variables: international business skills, managerial competence and risk-taking characteristics.

The hypotheses were tested by evaluating OLS regression models (Table 2). Notably, model 1 presents full model and control model using hierarchical regression analysis (Table 2). Initially, only control variables were entered. Later on, the characteristics of board human capital were added. The data presented in control model reveal that SMEs from manufacturing, mining and quarrying and other industry and starting internationalization earlier demonstrate higher internationalization performance. Meanwhile, full model demonstrates that risk-taking characteristics $(\mathrm{B}=0.714, \mathrm{p}<0.05$; ), international business skills $(\mathrm{B}=0.474$; $\mathrm{p}<0.05$ ) were found to have significant impact on internationalization performance and support hypothesis $\mathrm{H} 1 \mathrm{a}$ and $\mathrm{H} 1 \mathrm{c}$. The results revealed that some characteristics of board predict board's involvement in internationalization decisions.

A regression model was run to test hypotheses $\mathrm{H} 2 \mathrm{a}, \mathrm{H} 2 \mathrm{~b}$ and $\mathrm{H} 2 \mathrm{c}$. The model 2 in Table 2 shows that international business skills, managerial competence and risk-taking characteristics have a significant positive impact on the usage of knowledge and skills $(B=0.292$, $\mathrm{p}<0.05 ; \mathrm{B}=0.496, \mathrm{p}<0.05 ; \mathrm{B}=0.623, \mathrm{p}<0.001$ ), provides support for the hypothesis $\mathrm{H} 2 \mathrm{a}$, $\mathrm{H} 2 \mathrm{~b}, \mathrm{H} 2 \mathrm{c}$. 
Table 2. OLS regression models for board's characteristics and internationalization performance with unstandardized coefficients (source: own calculations)

\begin{tabular}{|c|c|c|c|c|c|c|c|c|c|c|c|}
\hline \multirow{3}{*}{ Outcome } & \multicolumn{5}{|c|}{ Model 1} & & \multicolumn{2}{|c|}{ Model 2} & & \multicolumn{2}{|c|}{ Model 3} \\
\hline & \multicolumn{5}{|c|}{$\begin{array}{c}\text { Internationalization } \\
\text { performance }\end{array}$} & & \multicolumn{2}{|c|}{$\begin{array}{l}\text { Usage of knowledge } \\
\text { and skills }\end{array}$} & & \multicolumn{2}{|c|}{$\begin{array}{c}\text { Internationalization } \\
\text { performance }\end{array}$} \\
\hline & \multicolumn{2}{|c|}{ Control model } & & \multicolumn{2}{|c|}{ Full model } & & & & & & \\
\hline Predictor & B & SE & & B & SE & & B & SE & & B & SE \\
\hline Constant & 2.906 & 0.279 & & 0.158 & 0.611 & & $1.101^{\star * *}$ & 0.330518425 & & 0.176 & 0.650 \\
\hline $\begin{array}{l}\text { Interna- } \\
\text { tional } \\
\text { business } \\
\text { skills }\end{array}$ & & & $\mathrm{c} 1$ & $0.474^{\star}$ & 0.134 & al & $0.292^{*}$ & 0.075 & $c^{\prime} 1$ & $0.378^{\star}$ & 0.122 \\
\hline $\begin{array}{l}\text { Manage- } \\
\text { rial com- } \\
\text { petence }\end{array}$ & & & c2 & 0.529 & 0.169 & a2 & $0.496^{\star}$ & 0.077 & $c^{\prime} 2$ & 0.366 & 0.157 \\
\hline $\begin{array}{l}\text { Risk-ta- } \\
\text { king cha- } \\
\text { racteristics }\end{array}$ & & & c3 & $0.714^{*}$ & 0.191 & a3 & $0.623^{* * *}$ & 0.068 & c'3 & $0.506^{*}$ & 0.180 \\
\hline $\begin{array}{l}\text { Usage of } \\
\text { knowledge } \\
\text { and skills }\end{array}$ & & & & & & & & & b & $0.330^{*}$ & 0.152 \\
\hline $\begin{array}{l}\text { Control } \\
\text { variables: }\end{array}$ & & & & & & & & & & & \\
\hline $\begin{array}{l}\text { Sector: } \\
\text { Manufac- } \\
\text { turing, mi- } \\
\text { ning and } \\
\text { quarrying } \\
\text { and other } \\
\text { industry }\end{array}$ & $0.767^{\star \star}$ & 0.250 & & $0.676^{* *}$ & 0.231 & & -0.086 & 0.125 & & $0.675^{\star *}$ & 0.232 \\
\hline $\begin{array}{l}\text { Sector: } \\
\text { Const- } \\
\text { ruction }\end{array}$ & -0.482 & 0.275 & & -0.372 & 0.250 & & $0.291^{\star}$ & 0.135 & & -0.367 & 0.257 \\
\hline Firm size & 0.089 & 0.051 & & $0.095^{*}$ & 0.046 & & 0.036 & 0.025 & & $0.096^{*}$ & 0.047 \\
\hline $\begin{array}{l}\text { Timing of } \\
\text { internatio- } \\
\text { nal market } \\
\text { entry }\end{array}$ & $-0.177^{\star}$ & 0.085 & & -0.129 & 0.079 & & -0.068 & 0.043 & & -0.130 & 0.080 \\
\hline Board size & 0.079 & 0.052 & & 0.065 & 0.048 & & 0.041 & 0.026 & & 0.066 & 0.049 \\
\hline Firm age & -0.012 & 0.010 & & -0.01 & 0.009 & & 0.005 & 0.005 & & -0.009 & 0.009 \\
\hline $\mathrm{R}$ & 0.496 & & & 0.637 & & & 0.758 & & & 0.637 & \\
\hline R Square & 0.246 & & & 0.405 & & & 0.574 & & & 0.405 & \\
\hline $\begin{array}{l}\text { Adjusted } \\
\text { R Square } \\
\end{array}$ & 0.199 & & & 0.348 & & & 0.533 & & & 0.341 & \\
\hline $\mathrm{F}$ & $5.213^{* * *}$ & & & $7.038^{* * *}$ & & & $13.936^{* * *}$ & & & $6.267^{* * *}$ & \\
\hline
\end{tabular}

Note: ${ }^{* * *} \mathrm{p}<0.001 ;{ }^{* *} \mathrm{p}<0.01 ;{ }^{*} \mathrm{p}<0.05 ;(\mathrm{N}=103)$, Dependent variables: Internationalization performance; Usage of knowledge and skills. 
The models 2 and 3 (Figure 2) are decomposed from the full model presented in Figure 1, allowing to evaluate the existence and level of direct effects and indirect effects of international business skills, managerial competence, and risk-taking characteristics on internationalization performance through the usage of knowledge and skills (hypotheses H3a, H3b, H3c).
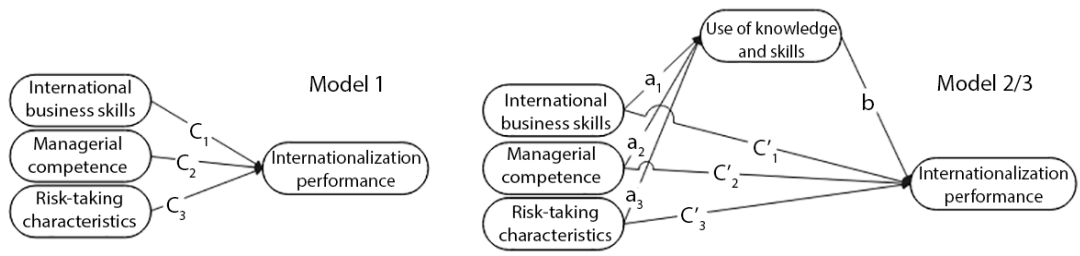

Figure 2. Decomposed conceptual model (Figure 1) referring to the OLS regression results (Table) 2 (own elaboration)

Coefficients a1, a2, a3, and b jointly allow estimating the indirect effect of international business skills, managerial competence, and risk-taking characteristics through the usage of knowledge and skills on internationalization performance, whereas c'1, c'2, and c'3, capture the direct effect of the board of directors characteristics on internationalization performance. As such, model 2 and model 3 decompose model 1 into such that direct and indirect effects can be assessed; or: $c 1=c^{\prime} 1+a 1 \times b$ and $c 2=c^{\prime} 2+a 2 \times b$.

These hypotheses were tested by evaluating the mediation of usage of knowledge and skills through regression-based path analysis presented in Table 2, with PROCESS macro to estimate and evaluate the indirect effects (Hayes et al., 2017). The estimated indirect effects of significant mediation presented in Table 3 revealed that usage of knowledge and skills significantly mediates the relationship between international business skills and internationalization performance (effect $=0.0964$; CI $0.0103-0.1785$ ) at a $95 \%$ level of confidence.

Table 3. The results of mediation analysis (source: own calculations)

\begin{tabular}{|l|l|c|c|c|c|}
\hline \multicolumn{7}{|c|}{ Indirect effect of X on Y through mediator - usage of knowledge and skills } \\
\hline \multicolumn{1}{|c|}{ Dependent variable (Y) } & $\begin{array}{c}\text { Independent } \\
\text { variable (X) }\end{array}$ & B & SE & LLCI & ULCI \\
\hline $\begin{array}{l}\text { Internationalization } \\
\text { performance }\end{array}$ & $\begin{array}{l}\text { International } \\
\text { business skills }\end{array}$ & 0.0964 & 0.516 & 0.0103 & 0.1785 \\
\hline $\begin{array}{l}\text { Internationalization } \\
\text { performance }\end{array}$ & $\begin{array}{l}\text { Managerial } \\
\text { competence }\end{array}$ & 0.1412 & 0.0973 & -0.0269 & 0.2910 \\
\hline $\begin{array}{l}\text { Internationalization } \\
\text { performance }\end{array}$ & $\begin{array}{l}\text { Risk-taking } \\
\text { characteristics }\end{array}$ & 0.0826 & 0.1315 & -0.1390 & 0.2900 \\
\hline
\end{tabular}

Note: ${ }^{\star}$ Lower and upper level confidence intervals (LLCI, ULCI) exclude zero, indicating significant mediation.

The results provided support the hypothesis H3a. Finally, for the robustness purpose, mediation results were confirmed by the Sobel test, which revealed that the usage of knowledge and skills mediate the relationships between international business skills and internationalization performance $(\mathrm{Z}=2.6207, \mathrm{p}<0.01)$. 


\section{Discussion}

We set forth to investigate how characteristics of board capital affect usage of knowledge and skills and subsequently firm's internationalization performance. Grounded on human capital, international entrepreneurship and upper-echelons theories (Barroso et al., 2011; Zattoni et al., 2015) we developed and tested a model, which indicates how characteristics of boards influence usage of knowledge and skills which can be reflected in the small firm's internationalization performance.

The findings revealed that some characteristics of board predict board's involvement in internationalization decisions of small firms. The results echo other studies demonstrating that international experience of board members is positively associated with internationalization (Oxelheim et al., 2013; Chen et al., 2016, 2017). While the literature emphasizes various disagreements of board members or even conflicting situations (Chen et al., 2016), the effectiveness of board members in exchanging information and opinions appears the most significant. Therefore, drawing on previous studies (Zattoni et al., 2015), we hypothesized that usage of knowledge and skills mediate the relationship between characteristics of human capital and internationalization. Furthermore, the data demonstrate that the relationship between international business skills and internationalization performance is mediated by usage of knowledge and skills. Higher levels of international business skills are positively related to the usage of knowledge and skills demonstrated during the meetings, in turn influencing higher level of internationalization performance. This suggest that international business skills of board lead to more efficient decision-making process and fulfillment of tasks related to the firm's internationalization barriers. The failure to detect a mediation path between managerial competence and risk-taking characteristics and internationalization performance through the usage of knowledge and skills might be related to the fact that international business skills of board are more significant for the managers and entrepreneurs of small firms and thus, are more visible during the meetings. Considering the fact, that board members are more involved in the advice function (Åberg et al., 2019) during decision-making process related to internationalization of small firm, the reverse effect of internationalization performance and risk-taking characteristics or managerial competence of board are less visible and take much longer to be observed. These findings echo other studies demonstrating that risk-tasking characteristics are not necessarily aligned with international orientation of the firm (Baum et al., 2013). Nevertheless, board can be perceived as a significant asset facilitating strategic decision-making process in SMEs and especially in internationalization process.

The scholars suggest that sector should be controlled due to the institutional perspective (Bjørnåli et al., 2016). Notably, the organizational practices have implications on governance practices and potentially varies among the SMEs from different economic activities. Therefore, size and age of SMEs were controlled. The results of our study revealed that some characteristics of the firms such as, manufacturing, mining and quarrying and other industry and starting internationalization later were positively associated with internationalization performance. The firms which belong to manufacturing sector are more tended to achieve higher international performance as compared to the firms which belong to other sectors. Meanwhile, SMEs which started internationalization process later achieved higher internationalization performance. 


\section{Conclusions}

The obtained results have contribution to the extant knowledge and implications for managers and entrepreneurs of SMEs aiming to increase internationalization performance. First, the findings complement resource dependency theory by justifying the importance of the board and their rich human capital characteristics in the resource attainment of the firm, which is closely related to internationalization performance. Second, the need to have a board of directors in the firms increases together with the expansion of business, due to the lack of resources and shortage of capital in SMEs. While less investigated in small firms' context, our results demonstrated the significance of board members in strategic decisions such as internationalization. Therefore, the attraction and employment of board members with higher international business skills is relevant for the international SMEs. Moreover, top managers, including board members, might consider development of particular competencies indicated as significant in this research, aiming to build a competitive advantage and increase SMEs success in the international arena.

Third implication relates to the effective usage of knowledge and skills of board members as the process through which boards contribute to international performance. This statement corresponds to the general truth that characteristics of human capital per see without effective use won't bring any tangible results. Hence, the study contributes to the literature on board and internationalization of SMEs by extending prior studies with the mediating effect of usage of knowledge and skills to the relationship between characteristics of board human capital and internationalization performance. Finally, obtained results bring essential insights on the board's contribution to international performance of SMEs operating in the context of Central and Eastern Europe.

A few limitations of our study can be emphasized. Firstly, the limitations are related to the cross-sectional data. Though our study advanced the theory by disclosing causality of the hypotheses, the longitudinal analysis should be considered in the future studies. Secondly, the research did not focus on a particular business sector, which might have certain specifics of the internationalization process. More extensive results might be achieved by combining several complementary studies in this field on specific business sectors. Thirdly, the results were obtained in one country context and thus, did not consider peculiarities common to other countries. The future studies should include other countries with similar institutional environment in the investigation, aiming to get more comprehensive results basis. Finally, the future studies could consider other characteristics of human capital.

\section{References}

Åberg, C., Bankewitz, M., \& Knockaert, M. (2019). Service tasks of board of directors: A literature review and research agenda in an era of new governance practices. European Management Journal, 37(5), 648-663. https://doi.org/10.1016/j.emj.2019.04.006

Åberg, C., \& Torchia, M. (2020). Do boards of directors foster strategic change? A dynamic managerial capabilities perspective. Journal of Management and Governance, 24, 655-684.

https://doi.org/10.1007/s10997-019-09462-4 
Arzubiaga, U., Kotlar, J., De Massis, A., Maseda, A., \& Iturralde, T. (2018). Entrepreneurial orientation and innovation in family SMEs: Unveiling the (actual) impact of the Board of Directors. Journal of Business Venturing, 33(4), 455-469. https://doi.org/10.1016/j.jbusvent.2018.03.002

Bagheri, M., Mitchelmore, S., Bamiatzi, V., \& Nikolopoulos, K. (2019). Internationalization orientation in SMEs: The mediating role of technological innovation. Journal of International Management, 25(1), 121-139. https://doi.org/10.1016/j.intman.2018.08.002

Barroso, C., Villegas, M. M., \& Pérez-calero, L. (2011). Board influence on a firm's internationalization. Corporate Governance: An International Review, 19(4), 351-367. https://doi.org/10.1111/j.1467-8683.2011.00859.x

Barroso-Castro, C., Domínguez-CC, M., \& Rodríguez-Serrano, M. A. (2020). SME growth speed: The relationship with board capital, Journal of Small Business Management. https://doi.org/10.1080/00472778.2020.1717293

Bamiatzi, V. C., \& Kirchmaier, T. (2014). Strategies for superior performance under adverse conditions: A focus on small and medium-sized high-growth firms. International Small Business Journal, 32(3), 259-284. https://doi.org/10.1177/0266242612459534

Baum, M., Schwens, C., \& Kabst, R. (2013). International as opposed to domestic new venturing: The moderating role of perceived barriers to internationalization. International Small Business Journal: Researching Entrepreneurship, 31, 536-562. https://doi.org/10.1177/0266242611428343

Bjørnåli, E. S., \& Aspelund, A. (2012). The role of the entrepreneurial team and the board of directors in the internationalization of academic spin-offs. Journal of International Entrepreneurship, 10(4), 350-377. https://doi.org/10.1007/s10843-012-0094-5

Bjørnåli, E. S., Knockaert, M., \& Erikson, T. (2016). The impact of top management team characteristics and board service involvement on team effectiveness in high-tech start-ups. Long Range Planning, 49(4), 447-463. https://doi.org/10.1016/j.lrp.2015.12.014

Bužavaitė, M. \& Korsakienè, R. (2019). Human capital and the internationalisation of SMEs: A systemic literature review. Entrepreneurial Business and Economics Review, 7(3), 125-142. https://doi.org/10.15678/EBER.2019.070307

Calabrò, A., \& Mussolino, D. (2013). How do boards of directors contribute to family SME export intensity? The role of formal and informal governance mechanisms. Journal of Management \& Governance, 17(2), 363-403. https://doi.org/10.1007/s10997-011-9180-7

Chen, H. L., Chang, C. Y., \& Hsu, W. T. (2017). Does board co-working experience influence directors' decisions toward internationalization? Management International Review, 57(1), 65-92. https://doi.org/10.1007/s11575-016-0309-4

Chen, H. L., Hsu, W. T., \& Chang, C. Y. (2016). Independent directors' human and social capital, firm internationalization and performance implications: An integrated agency-resource dependence view. International Business Review, 25(4), 859-871. https://doi.org/10.1016/j.ibusrev.2015.10.010

European Commission. (2019). SBA Fact Sheet Lithuania. Retrieved from https://eimin.lrv.lt/uploads/ eimin/documents/files/Lithuania\%20-\%20SBA\%20Fact\%20Sheet\%202019.pdf

Gerschewski, S., Rose, E. L., \& Lindsay, V. J.. (2015). Understanding the drivers of international performance for born global firms: An integrated perspective. Journal of World Business, 50(3), 558-575. https://doi.org/10.1016/j.jwb.2014.09.001

Hayes, A. F., Montoya, A. K., \& Rockwood, N. J. (2017). The analysis of mechanisms and their contingencies: PROCESS versus structural equation modeling. Australasian Marketing Journal (AMJ), 25(1), 76-81. https://doi.org/10.1016/j.ausmj.2017.02.001

Hult, G. T. M., Ketchen, D. J., Griffith, D. A., Chabowski, B. R., Hamman, M. K., Dykes, B. J., \& Cavusgil, S. T. (2008). An assessment of the measurement of performance in international business research. Journal of International Business Studies, 39(6), 1064-1080.

https://doi.org/10.1057/palgrave.jibs. 8400398 
Hsu, C. C., Tan, K. C., Laosirihongthong, T., \& Leong, G. K. (2011). Entrepreneurial SCM competence and performance of manufacturing SMEs. International Journal of Production Research, 49(22), 6629-6649. https://doi.org/10.1080/00207543.2010.537384

Karami, M., \& Tang, J. (2019). Entrepreneurial orientation and SME international performance: The mediating role of networking capability and experiential learning. International Small Business Journal, 37(2), 105-124. https://doi.org/10.1177/0266242618807275

Kearney, E., Gebert, D., \& Voelpel, S. C. (2009). When and how diversity benefits teams: The importance of team members' need for cognition. Academy of Management Journal, 52(3), 581-598. https://doi.org/10.5465/AMJ.2009.41331431

Korsakienè, R., Bekešienè, S., \& Hošková-Mayerová, Š. (2019a). The effects of entrepreneurs' characteristics on internationalisation of gazelle firms: A case of Lithuania. Economic ResearchEkonomska Istrazivanja 32: 2864-2881. https://doi.org/10.1080/1331677X.2019.1655658

Korsakienè, R., Kozak, V., Bekešienè, S., \& Smaliukiene, R. (2019b). Modelling internationalization of high growth firms: micro level approach. E\&M Economics and Management $=E \& M$ Ekonomie a management, 22(1), 54-71. https://doi.org/10.15240/tul/001/2019-1-004

Kungwansupaphan, C., \& Siengthai, S. (2014). Exploring entrepreneurs' human capital components and effects on learning orientation in early internationalizing firms. International Entrepreneurship and Management Journal, 10, 561-587. https://doi.org/10.1007/s11365-012-0237-0

Oxelheim, L., Gregorič, A., Randøy, T., \& Thomsen, S. (2013). On the internationalization of corporate boards: The case of Nordic firms. Journal of International Business Studies, 44(3), 173-194. https://doi.org/10.1057/jibs.2013.3

Podsakoff, N. P. (2003). Common method biases in behavioral research: a critical review of the literature and recommended remedies. Journal of Applied Psychology, 88(5), 879-903.

https://doi.org/10.1037/0021-9010.88.5.879

Preacher, K. J., \& Hayes, A. F. (2008). Contemporary approaches to assessing mediation in communication research. In A. F. Hayes, M. D. Slater, \& L. B. Snyder (Eds.), The Sage sourcebook of advanced data analysis methods for communication research (pp. 13-54). Sage Publications, Inc. https://doi.org/10.4135/9781452272054.n2

Puthusserry, P., Khan, Z., Nair, S. R., \& King, T. (2021). Mitigating psychic distance and enhancing internationalization of fintech SMEs from emerging markets: The role of board of directors. British Journal of Management, 32(4), 1097-1120. https://doi.org/10.1111/1467-8551.12502

Ricci, F., Scafarto, V., Moscarini, F., \& Della Corte, G. (2019). The concept of board capital in corporate governance research: A structured literature review. In S. Esposito De Falco, F. Alvino, \& A. Kostyuk (Eds.), New challenges in corporate governance: Theory and practice (pp. 333-348). https://doi.org/10.22495/ncpr_44

Rivas, J. L. (2012). Diversity \& internationalization: The case of boards and TMT's. International Business Review, 21(1), 1-12. https://doi.org/10.1016/j.ibusrev.2010.12.001

Roffia, P., Simón-Moya, V., \& García, J. S. (2021). Board of director attributes: Effects on financial performance in SMEs. International Entrepreneurship and Management Journal. https://doi.org/10.1007/s11365-020-00715-5

Rogelberg, S. G., \& Stanton, J. M. (2007). Introduction: understanding and dealing with organizational survey nonresponse. Organizational Research Methods, 10, 195-209. https://doi.org/110.1177/1094428106294693

Zattoni, A., Gnan, L., \& Huse, M. (2015). Does family involvement influence firm performance? Exploring the mediating effects of board processes and tasks. Journal of Management, 41(4), 12141243. https://doi.org/10.1177/0149206312463936 